\title{
Türkçe Öğretmeni Adaylarının Akademik Erteleme Davranışları ile Akademik Öz Yeterlikleri Arasındaki İlişkinin İncelenmesi ${ }^{1}$
}

\section{Murat Şengül 2}

\author{
Rafet Özer Seyfi ${ }^{3}$
}

\author{
Type/Tür: \\ Research/Araştırma \\ Received/Geliş Tarihi: \\ November 5/5 Kasim 2019 \\ Accepted/Kabul Tarihi: \\ June 15/15 Haziran 2020 \\ Page numbers/Sayfa No: \\ 755-773 \\ Corresponding \\ Author/Illetişimden \\ Sorumlu Yazar: \\ muratsengul@nevsehir.edu.t \\ $\underline{r}$
}

\section{$\checkmark$ iThenticate}

This paper was checked for plagiarism using iThenticate during the preview process and before publication. / $\mathrm{Bu}$ çalışma ön inceleme sürecinde ve yayımlanmadan önce iThenticate yazılımı ile taranmıştır.

Copyright (C) 2017 by Cumhuriyet University, Faculty of Education. All rights reserved.

\section{Öz}

$\mathrm{Bu}$ araştırmanın amacı, Türkçe öğretmeni adaylarının akademik erteleme davranışları ve akademik öz yeterlikleri ile ilgili görüşleri arasındaki ilişkiyi belirlemektir. Çalışmada ilişkisel tarama modeli kullanılmıştır. Araştırmanın örneklemini Türkiye İstatistik Kurumu (TÜIK) tarafından ortaya konan istatistiki bölge birimlerinden seçilen 13 ilde bulunan devlet üniversitelerindeki eğitim fakültelerinin Türkçe öğretmenliği programlarında 20172018 eğitim-öğretim yılında öğrenim görmekte olan 4. sınıf öğrencisi 557 Türkçe öğretmeni adayı oluşturmaktadır. Araştırmada, veri toplama aracı olarak "Kişisel Bilgi Formu", "Akademik Erteleme Davranışı Ölçeği" ve "Akademik Öz Yeterlik Ölçeği" kullanılmıştır. Türkçe öğretmeni adaylarının akademik erteleme davranışı düzeyleri incelediğinde; Sorumsuzluk ( $\bar{X}=2.62)$, Akademik Görevin Alg1lanan Niteliği $(\bar{X}=2.31)$, Öğretmenlere İlişkin Olumsuz Algı $(\bar{X}=3.15)$, Akademik Mükemmeliyetçilik $(\bar{X}=2.77)$ boyutlarının ortalamaların dengeli dağıldığı, Türkçe öğretmeni adaylarının, Akademik Görevin Algılanan Niteliği boyutunda düşük düzeyde ve diğer boyutlarda orta düzeyde bir puana sahip oldukları tespit edilmiştir. Türkçe öğretmeni adaylarının akademik öz yeterlik düzeyleri incelendiğinde, Bilişsel Uygulamalar $(\overline{\mathrm{X}}=3.21)$, Sosyal Statü $(\overline{\mathrm{X}}=2.83)$, Teknik Beceriler ( $\bar{X}=3.02$ ) boyutlarının ortalamalarının dengeli dağıldı $\breve{g}_{1}$ ve puanların orta düzeyde olduğu saptanmıştır. Akademik Erteleme Davranışı Ölçeği genel aritmetik ortalamasının orta düzeyde olduğu ( $\bar{X}=2.61)$, Akademik Öz yeterliğin genel aritmetik ortalamasının da orta düzeyde olduğu $(\bar{X}=3.07)$ tespit edilmiştir. Araştırma sonucunda, akademik erteleme davranışı ile akademik öz yeterlik arasındaki negatif yönde düşük seviyede ilişki tespit edilmiştir. Akademik öz yeterliğin akademik erteleme davranışını yordayıp yordamadığına bakıldığında Teknik Beceriler hariç diğer akademik öz yeterlik boyutlarının akademik erteleme davranışını yordadığı görülmüştür.

Anahtar Sözcükler: Türkçe öğretmeni adayları, akademik erteleme davranışı, akademik öz yeterlik, erteleme, öz yeterlik.

\section{Suggested APA Citation/Önerilen APA Atıf Biçimi:}

Şengül, M., \& Seyfi, R. Ö. (2020). Türkçe öğretmeni adaylarının akademik erteleme davranışları ile akademik öz yeterlikleri arasındaki ilişkinin incelenmesi. Cumhuriyet Uluslararası Ĕ̆itim Dergisi, 9(3), 755-773. http://dx.doi.org/10.30703/cije.643239

\footnotetext{
${ }^{1} \mathrm{Bu}$ makale, birinci yazarın danışmanlığında, ikinci yazar tarafından hazırlanan "Türkçe Öğretmeni Adaylarının Akademik Erteleme Davranışları ile Akademik Öz Yeterlikleri Arasındaki İlişkinin İncelenmesi” adlı yüksek lisans tezinden özetlenerek hazırlanmıştır.

${ }^{2}$ Doç. Dr., Nevşehir Hacı Bektaş Veli Üniversitesi Eğitim Fakültesi Türkçe ve Sosyal Bilimler Eğitimi Bölümü Türkçe Eğitimi Anabilim Dalı

e-mail: muratsengul@nevsehir.edu.tr ORCID ID: https:/ / orcid.org/0000-0003-2163-9420

3 Türkçe Öğretmeni, Muş Bulanık Yokuşbaşı Ortaokulu e-mail: rafetozerseyfi@gmail.com ORCID ID: https:/ / orcid.org/0000-0002-4859-9003
} 


\title{
Investigation of the Relationship between Academic Procrastination Behaviours and Academic Self-efficacy of Turkish Language Teacher Candidates
}

\begin{abstract}
The aim of this study is to investigate the relationship between Turkish language teacher candidates' academic procrastination behaviors and academic self-efficacy. Relational screening model was used in this study. The sample of the research is constituted of 557 senior students who are candidate Turkish language teachers studying at education faculties of 13 state universities selected by Turkish Statistical Institute's regional units at 2017-2018 academic year. At the study "Personal Information Form", "Academic Procrastination Scale" and "Academic Self-Efficacy Scale" were used as data collection tools. When Turkish language teacher candidates' academic procrastination level was investigated, the mean scores of irresponsibility $(\overline{\mathrm{X}}=2.62)$, Perceived Quality of Academic Task $(\overline{\mathrm{X}}=2.31)$, Negative Perception of Teachers $(\overline{\mathrm{X}}=3.15)$, Academic Perfectionism $(\overline{\mathrm{X}}=2.77)$ dimensions were distributed balanced and it was determined that Turkish language teacher candidates' Perceived Quality of Academic Task dimension has low level mean score and the other dimensions have moderate level mean score. When Turkish language teacher candidates' academic selfefficacy levels were investigated, the mean scores of Cognitive Practices $(\bar{X}=3.21)$, Social Status $(\overline{\mathrm{X}}=2.83)$, and Technical Skills $(\overline{\mathrm{X}}=3.02)$ were at moderate level and distributed balanced. It was detected that both of the mean scores obtained from Academic Procrastination Behavior Scale $(\overline{\mathrm{X}}=2.61)$ and Academic Self-efficacy Scale $(\overline{\mathrm{X}}=3.07)$ found to be at moderate level. As a result of the research, low level of negative correlation was found between academic procrastination and academic self-efficacy. Whether academic self-efficacy predicted academic procrastination behavior was investigated, it was observed that all Academic Self-efficacy dimensions but Technical Skills were predictor of the academic procrastination.
\end{abstract}

Keywords: Turkish language teacher candidates, Academic Procrastination, academic self-efficacy, Procrastination, self-efficacy.

\section{Giriş}

Günümüz insanı, çalışma veya eğitim hayatında yapması gereken işleri çalışma enerjisi ve imkânı olmasına rağmen hep ileri atma eğilimi içerisindedir. Bu eğilimin etkisiyle yapacağı işlere başlamadan hemen önce genellikle dikkatini çeken, ilgi duyduğu, aktivitelere yönelme eğilimindedir. Yapılması gereken işler için gayret edip tamamlamak yerine film izlemek, arkadaşlarıyla veya sosyal medyada vakit geçirmek, yoğun ve yorgun olduğunu söylemesi gibi çeşitli bahaneler bularak ve kaçınarak, ağırdan alarak görevlerini ertelerler. Birey, yapacağı işlere hep "Biraz sonra başlarım." cümlesini zihninden geçirir ama bir türlü işe başlayamaz. Bu durum, bir zaman sonra hayatında aksamalara sebep olur. Bu durumda günümüz insanlarının günlük yaşam, iş ve eğitim hayatlarında en büyük sorunlarından olan erteleme birçok araştırmacı tarafından tanımlanmıştır. Grecco (1984) ertelemeyi, bir işi yapmak için harekete geçmeyi veya o işi tamamlamayı isteyerek ve bilerek geciktirme olarak tanımlarken bir başka tanım ertelemeyi bireyin bir iş için sorumluluk almayı, karar vermeyi ve yerine getirmesi gereken görevi başka bir zamana bırakması olarak ifade etmektedir (Milgram, Mey-Tal ve Levison, 1998). Buna göre, ertelemeyi bir görevin ileri bir zamana atılması veya geciktirilmesi şeklinde ifade etmek mümkündür. Akademik temelli görevleri ihtiva eden ve erteleme kavramının önemli bir türü olan akademik erteleme davranışı; akademik işlerin çeşitli nedenlerle geciktirilmesi veya yapmaktan kaçınılması şeklinde ifade edilmiştir (Aktaran: Gürültü, 2016). Her yaştan ve 
cinsiyetten kişide görülen erteleme davranışının birçok nedeni vardır. Milgram (1992), ertelemenin modern bir hastalık olduğunu ve erteleme davranışının teknolojisi ve sanayisi gelişmiş, planlı ve programlı olmanın önemli olduğu toplumlarda yaygın olarak görüldüğünü belirtmiştir (Aktaran: Çakıc1, 2003). Ancak ertelemenin nedeni sadece bu değildir. Modern çağın doğurduğu birçok sebep vardır. Emmett (2004), işin sevilmemesi, güdülenme eksikliği, mükemmeliyetçilik, başarı korkusu, değişim korkusu, bireylerin iş yüklerinin yoğunluğu gibi altı erteleme nedeni belirtirken yapılan diğer çalışmalara bakıldığında, zaman yönetimi konusunda yetersizlik (McCown, Petzel ve Rupert, 1987), amaç ve hedef belirleyememe ve motivasyon eksikliği (Balkıs, 2006; Kağan, 2009), cinsiyet (Aydoğan, 2008; Akkaya, 2007; Balk1s, 2006; Çetin, 2009), mükemmeliyetçilik (Çakıc1, 2003; Sarıŏlu 2011), başarısızlık korkusu (Solomon ve Rothblum, 1984), düşük özsayg1 (Çakı1c1, 2003), düşüuk yeterlilik alg1sı (Gülebağlan, 2003), kayg1 (Güner, 2008) gibi birçok değişkenin ertelemeye neden olduğu görülmektedir. Bunların dışında, stres ve hastalıklar (Shanahan ve Neufeld, 2010; Tice ve Baumeister, 1997), depresyon (Van Eerde, 2003), ödevin teslim tarihini kaçırma ve akademik performansın düşüklüğü (Beck, Koons ve Milgrim, 2000; Beswick, Rothblum ve Mann 1988), akademik gelişimde aksama ya da gerileme, iş hayatında problemler, düşük verim, ikili ilişkilerde gerginlik (Haycock, McCarthy ve Skay 1998) gibi sebepler de ertelemeye sebep olan diğer faktörler olarak sıralanmaktadır. Özellikle, üniversite öğrencilerinin akademik görevlerini ertelemesine sebep olan bu gibi nedenler öfke ve stres seviyelerinin artması, kaygının oluşması, tükenmişlik, yorgunluk ve görevlerin üstünkörü şekilde yapılması gibi birçok sonucu doğuracaktır.

Bu çalışmada üzerinde durulan bir diğer kavram olan öz yeterlik, Senemoğlu (2007) tarafından, kişinin çeşitli vaziyet ve etkenlerle uğraşmak, gücü yetmek ve gerçekleştirmek istediği faaliyeti başarma, gerçekleştirme kudreti ve kabiliyetine ilişkin kendi hakkındaki kanaat ve inancını bilmesi diye tanımlanırken, Schunk (1985) tarafından akademik öz yeterlik değişkeni öğrencilerin eğitsel işleri yapabilmeye olan güvenleri olarak ifade edilmiştir. Öz yeterliği yüksek öğrenciler veya öğretmenler verilen bir görevi yapmaktan kaçmayacaktır. Verilen görevi yapabileceğine olan inancı yüksek olanlar o görevi nerede ve nasıl yapacağını bilecektir. Bir plan çerçevesinde, zamanı kontrol ederek yapması gereken bir işi veya akademik görevini yerine getirecek, motivasyonu ve kendine güveni artacaktır. Öz yeterliği yüksek olan birey, kendi kapasitesinin yani neler yapabileceğinin farkındadır. Öz yeterliği yüksek olmayan öğrenci veya öğretmenler ise planlamadan uzak, kayg1 ve stres içinde, zaman israfı yaparak görevi erteleyen bir durumda olacaktır. Açıkgöz Ün (2003), yetkin bir öğretmenin, öğretim sürecinin nasıl yapılıp ve nasıl ilerleteceğinin, ayrıca bu süreç içerisinde ortaya çıkabilecek sorunlara nasıl müdahale edip çözüme kavuşturacağının bilincinde; süreçte, tecrübelerini ve bilgilerini yerinde, zamanında nasıl aktaracağının farkında olması gerektiğini ifade eder. Bu durum, güçlü bir öz yeterlik anlayışını ve bunun neticesinde ertelemeden uzak bir tutumu beraberinde getirecektir.

Literatür incelendiğinde, bu çalışmada üzerinde durulan akademik erteleme davranışı ve akademik öz yeterlik kavramlarıyla ilgili çalışmaların yapıldığı görülmektedir. Bu iki kavramın çeşitli değişkenlerle olan ilişkilerinin ve düzeylerinin gerçekleştirilen çalışmalarla ortaya konulduğu görülmektedir. Bu durumla alakalı birçok çalışma sıralayabiliriz: Balkıs ve Duru (2009), üniversite öğrencilerinin öz 
saygının erteleme davranışlarına etkisini belirlemek amacıyla yaptıkları çalışmada, öğretmen adayların \% 23 oranında yüksek düzeyde erteleme davranışı göstermiş olduklarını, erteleme davranışıyla akademik başarı arasında negatif yönde ilişki olduğunu tespit etmişlerdir. Akbay ve Gizir (2010), cinsiyete göre akademik erteleme davranışının akademik güdülenme, akademik yükleme sitilleri, akademik öz yeterliği yordayıp yordamadığını ortaya koymak için yaptıkları çalışma sonucunda akademik güdülenme, akademik öz yeterlik ve akademik yükleme stillerinin üniversite öğrencilerinin akademik erteleme davranışını yordadığını, kızların akademik erteleme eğilimlerine akademik öz yeterlik inançlarının katkısı olmadığını belirlemiştir. Çetin (2009), “Eğitim Fakültesi Öğrencilerinin Akademik Erteleme Davranışlarına İlişkin Görüşlerinin İncelenmesi” adlı çalışmasında örneklemdekilerin \% 33' ünün yüksek, \% 34' ünün orta düzeyde erteleme davranışı gösterdiğini, akademik erteleme davranışının cinsiyete, başarı durumuna ve ikamet şekline göre farklılaştığı sonuçlarına ulaşılmıştır. Çelikkaleli ve Akbay (2013), üniversite öğrencilerinin akademik erteleme davranışlarının başkalarına karşı sorumluluk, genel yetkinlik inançları, kendilerine karşı sorumluluk düzeyleriyle anlamlı ilişki oluşturduğunu belirlemiştir. Odacı ve Berber Çelik (2012), üniversite öğrencilerinin problemli internet kullanımlarıyla akademik öz yeterlik, akademik erteleme ve yeme tutumları arasındaki ilişkileri incelemek amacıyla yaptıkları çalışma sonucunda; problemli internet kullanımı arttıkça akademik öz yeterliğin azaldığı ve yeme bozukluklarının oluşmasını problemli internet kullanımının yordadığı; akademik erteleme davranışları ile problemli internet kullanımı arasında anlamlı ilişki olmadığı sonucuna ulaşmıştır. Kavrayıcı ve Bayrak (2016), 2013-2014 öğretim yılında Anadolu Üniversitesi Eğitim Fakültesi Pedagojik Formasyon Sertifika Programında öğrenim gören öğretmen adayları üzerinde yaptıkları araştırma sonucunda öz yeterlik algılarının "çok yeterli" düzeyinde olmadı̆̆ı ancak toplam öz yeterlik algılarının ve öğrencinin katılımının sağlanması, öğretim stratejileriyle sınıf yönetimi öz yeterlik algılarının "oldukça yeterli" düzeyde olduğu sonucuna ulaşmışlardır. Tabancalı ve Çelik (2013) tarafından yapılan çalışmada, öğretmen adaylarının akademik öz yeterliği ile öğretmenlik öz yeterliği arasında pozitif yönde ilişki olduğu, yüksek akademik öz yeterliğe sahip olanların düşük ve orta olanlara göre öğretmen öz yeterlik alt boyutlarının her birinde daha iyi oldukları; akademik öz yeterlikleri ile öğretmen öz yeterliklerinin yüksek olduğu; Öz yeterliği fazla olan kişilerin başladıkları bir işi sonuca ulaştırmak için fazla derecede gayret sarf ettikleri ve bu süreçte karşılarına çıkan engelleri aşmakta daha kararlı oldukları ve ayrıca ilerledikleri yoldan kolayca dönmedikleri sonuçlarına ulaşılmıştır.

Akademik erteleme davranışı ve akademik öz yeterlik kavramlarının farklı kavram ve değişkenlerle ilişkisini ortaya koyan söz konusu çalışmalardan hareketle araştırmanın temel amacı, Türkçe öğretmen adaylarının akademik erteleme davranışı ve akademik öz yeterlik düzeylerine ilişkin görüşlerinin saptanması ve akademik erteleme davranışı ve akademik öz yeterlikleri arasındaki ilişkinin ortaya çıkarılması olarak belirlenmiştir. Bu temel amaç doğrultusunda aşağıdaki sorulara cevap aranmıştır:

1. Türkçe öğretmeni adaylarının akademik erteleme davranışı ("sorumsuzluk", "akademik görevin algilanan niteliği", "öğretmenlere ilişkin olumsuz algı”, “akademik mükemmeliyetçilik” boyutlarında) ne düzeydedir? 
2. Türkçe öğretmeni adaylarının akademik öz yeterlikleri ("sosyal statü", "bilişsel uygulamalar" ve "teknik beceriler" boyutlarında) ne düzeydedir?

3. Türkçe öğretmeni adaylarını akademik erteleme davranışları ile akademik öz yeterlikleri arasında ilişki var mıdır?

$\mathrm{Bu}$ araştırmada belirlenen temel amaç ve temel amaçtan hareketle çıkan sonuçların, öğretmen yetiştiren kurumlarda uygulanan eğitim programlarının geliştirilmesine katkı sağlayacağı, öğretmen seçiminde farklı ölçütlerin yanı sıra, öğretmenin akademik erteleme davranışları ile akademik öz yeterlikleri arasındaki ilişkinin tespit edilmesinin bu yöndeki yaşanacak gelişmelere katkı sağlayacağı, hizmet içi eğitimlerin daha nitelikli olmasında katkı sağlayacağı ve öğretmen seçiminde akademik öz yeterlikleri de göz önünde bulundurularak daha etkili ve başarılı bir uygulama yapılmasına alt yapı sağlayacağı, Türkçe öğretmenliği lisans programının bir çıktısı olan Türkçe öğretmeni adaylarının niteliklerinin resmedilmesine katkıda bulunacağ1 düşünülmektedir.

\section{Araştırmanın Modeli}

\section{Araştırmanın Yöntemi}

$\mathrm{Bu}$ araştırmada tarama modellerinden ilişkisel araştırma modeli kullanılmıştır. İlişkisel araştırma modelinde iki değişken arasında beraber değişim ve değişimin derecesi tespit edilmeye çalışılır (Karasar, 2012). Yapılan bu araştırmada Türkçe öğretmeni adaylarının akademik erteleme davranışları ile akademik öz yeterlikleri arasındaki ilişki belirlenmeye çalışılmıştır.

\section{Evren ve Örneklem}

Araştırmanın evrenini, 2017-2018 eğitim öğretim yılında, Türkiye'deki devlet üniversitelerinin eğitim fakültelerinde öğrenim gören Türkçe öğretmenliği programı dördüncü sınıf öğrencileri oluşturmaktadır. Araştırmanın örneklemini de Türkiye İstatistik Kurumunun (TUIK) ortaya koyduğu istatistikî bölge birimi sınıflandırmasına göre (Polat, 2009) 12 istatistiki bölge birimlerinden toplam 13 ilde (İstanbul, Edirne, Afyonkarahisar, Bolu, Konya, Adana, Kırşehir, Nevşehir, Amasya, Rize, Ağrı, Muş, Gaziantep) bulunan devlet üniversitelerindeki 557 Türkçe öğretmenliği programı dördüncü sınıf öğrencileri oluşturmaktadır. Örneklem grubuna ilişkin betimleyici istatistikler Tablo 1'de verilmiştir. 
Tablo 1

Türkçe Öğretmeni Adaylarının Demografik Özelliklerine İlişkin Betimleyici İstatistikler

\begin{tabular}{llcc}
\hline Değişken & Grup & $\mathbf{N}$ & $\mathbf{0}$ \\
\hline \multirow{2}{*}{ Cinsiyet } & Kadın & 341 & 61.2 \\
& Erkek & 216 & 38.8 \\
\hline \multirow{3}{*}{ Yaş Aralığı } & $17-20$ & 27 & 4.8 \\
& $21-25$ & 499 & 89.6 \\
& 26 veya üzeri & 31 & 5.6 \\
\hline & TR1 İstanbul & 24 & 4.3 \\
& TR2 Batı Marmara & 41 & 7.4 \\
& TR3 Ege & 55 & 9.9 \\
& TR4 Doğu Marmara & 25 & 4.5 \\
\multirow{2}{*}{ Öğrenim Gördükleri İstatistiki } & TR5 Batı Anadolu & 86 & 15.4 \\
& TR6 Akdeniz & 29 & 5.2 \\
& TR7 Orta Anadolu & 78 & 14 \\
& TR8 Batı Karadeniz & 33 & 5.9 \\
& TR9 Doğu Karadeniz & 27 & 4.8 \\
& TRA Kuzeydoğu Anadolu & 55 & 9.9 \\
& TRB Ortadoğu Anadolu & 43 & 7.7 \\
\hline Toplam & TRC Güneydoğu Anadolu & 61 & 11 \\
\hline
\end{tabular}

\section{Veri Toplama Araçları}

Araştırma için gerekli olan verilere ulaşmak amacıyla iki ölçek kullanılmıştır. Türkçe öğretmeni adaylarının akademik erteleme davranışı düzeylerini belirlemek için "Akademik Erteleme Davranışı Ölçeği", akademik öz yeterlik düzeylerini belirlemek için "Akademik Öz Yeterlik Ölçeği” kullanılmıştır. Öğrencilerin kişisel bilgileri için de "Kişisel Bilgi Formu" kullanılmıştır.

Kişisel bilgi formu. Katılımcıların kişisel bilgilerine ulaşmak için oluşturulmuştur.

Akademik erteleme davranışı ölçeği. Akademik Erteleme Davranışı Ölçeği (Ocak ve Bulut, 2015), öğretmen adaylarının erteleme davranışlarını belirlemek amacıyla oluşturulmuştur. Bu ölçek oluşturulurken genel tarama modeli kullanılmıştır. Araştırmanın örneklemi 381 öğretmen adayından oluşmaktadır. Analizler neticesinde, ölçeğin dört faktör ve 11 olumsuz, 27 olumlu toplam otuz sekiz maddeden oluştuğu görülmüsstür. I. faktörde yer alan maddeler akademik erteleme davranışıyla ilgili sorumsuzluğu, II. faktördeki maddelerin akademik görevin algılanan niteliğini, III. faktördeki maddelerin öğretmenlere ilişkin olumsuz algıyı, IV. faktördeki maddelerin akademik mükemmeliyetçiliği ölçtüğü tespit edilmiştir.

Akademik öz yeterlik ölçeği. Akademik Öz yeterlik Ölçeği (Ekici, 2012) çalışmasının amacı Owen ve Froman' in (1998) literatüre kazandırdığı ölçeğin dil uzmanlarınca Türkçeye çevrisi ve Türkçeye uygunluğu uzmanlarca değerlendirilerek geçerlik ve güvenirliğini test etmektir. Uzman görüşlerinden sonra da 681 üniversite öğrencisine uygulanmıştır. Ölçek, bilişsel uygulamalar boyutu, sosyal statü boyutu, teknik beceriler boyutları olmak üzere 33 maddeden oluşmaktadır. Elde edilen sonuçlar neticesinde, ölçeğin Türkiye' de uygulanabileceği sonucuna ulaşılmıştır. 
Çalışmada kullanılan ölçekler faktör analizi ve güvenirlik analizleri önceden yapılmış ölçeklerdir. Ölçeklerdeki faktörlerin bu çalışmada da güvenilir olup olmadığına bakmak için faktörlerin Cronbach's Alpha katsayılarına bakılmıştır.

Tablo 2

Araştırmada Kullanılan Akademik Erteleme Davranışı Ölçeğinin ve Akademik Öz Yeterlik Ölçeğinin Güvenilirlik Analizine İlişkin Veriler

\begin{tabular}{lccc}
\hline Boyutlar/Ölçekler & Soru Sayıs1 & $\overline{\mathbf{X}}$ & Cronbach's Alpha Katsayısı \\
\hline Sorumsuzluk & 19 & 2.62 & .943 \\
Akademik Görevin Algılanan Niteliği & 10 & 2.31 & .871 \\
Öğretmenlere İlişkin Olumsuz Alg1 & 5 & 3.15 & .833 \\
Akademik Mükemmeliyetçilik & 4 & 2.77 & .763 \\
\hline Akademik Erteleme Davranışı (Genel) & $\mathbf{3 8}$ & $\mathbf{2 . 6 2}$ & $\mathbf{. 9 3 4}$ \\
\hline Bilişsel Uygulama & 19 & 3.21 & .853 \\
Sosyal Statü & 10 & 2.83 & .772 \\
Teknik Beceriler & 4 & 3.02 & .553 \\
\hline Akademik Öz Yeterlik (Genel) & $\mathbf{3 3}$ & $\mathbf{3 . 0 7}$ & $\mathbf{. 9 0 0}$ \\
\hline
\end{tabular}

Tablo 2 incelendiğinde faktörlerdeki Cronbach's Alpha katsayısının uygun sınırlar içerisinde olduğu görülmektedir. Buna göre, er iki ölçeğin de yüksek güvenilirlik düzeyinde olduğu söylenebilir.

\section{Verilerin Toplanması ve Verilerin Analizi}

Türkiye İstatistik Kurumu (TUIK) bölgesel sınıflaması dikkate alınarak rastgele belirlenen 13 ilde bulunan Eğitim Fakültelerine araştırmacılardan biri bizzat gitmiştir. Katılımcılarla yüz yüze görüşerek Türkçe Öğretmenliği lisans programlarındaki 4. sınıf öğrencilerine 557 adet veri toplama aracını uygulamıştır.

Ölçeklerin örnekleme uygulanması sonrasında elde edilen veriler, ilgisayar ortamına aktarılmış ve istatistiki işlemler yapılmıştır. Katılımcıların akademik erteleme davranışı ve akademik öz yeterliğe dönük algıları belirlenirken ortalama, standart sapma hesaplaması yapılmıştır. Araştırmanın bağımlı değişkenlerini, akademik erteleme davranışı ve boyutları oluştururken, araştırmanın bağımsız değişkenlerini akademik öz yeterlik ve boyutları oluşturmaktadır. Katılımcıların ölçeklere verdiği cevaplar sonucu oluşan puan ortalamalarından hareketle ilişki analizinde Pearson Korelasyon Katsayısı kullanılmış, bağımsız değişkenlerin bağımlı değişken üzerindeki etkisine çoklu regresyon analizi ile bakılmıştır. İstatiksel verilerin analizi ve yorumların anlamlılık düzeyleri (p) .05 ve .01 olarak alınmıştır. Ulaşılan bulguların \% 95 ve \% 99 güven aralığında \% 95 için \% 5, \% 99 için \% 1 anlamlılık düzeyinde değerlendirilmiştir. Likert tipi ölçeğin değer farkının (5-1 = 4) değer yargısına (5) bölünmesiyle elde edilen .80' lik aralıklar, sıklık düzeyinin ve buna bağlı olarak ölçeklerin sınırlarını belirlemiştir. Buna göre, 1.00-1.80 arasında aritmetik ortalamaya sahip olan ölçek maddelerindeki sıklık düzeyi "çok düşük" olup 4.21-5.00 arasındakiler "yüksek" seviyede olup katılımcıların belirlenen davranışı gerçekleştirme seviyelerini hangi puan aralığına düşüyorsa ona göre yorumlanmıştır. 


\section{Bulgular \\ Akademik Erteleme Davranışına İlişkin Bulgular}

Türkçe öğretmeni adaylarının akademik erteleme davranışı düzeylerini belirlemek için öğretmen adaylarının Akademik Erteleme Davranışı Ölçeğinden aldıkları puanlar betimsel istatistik analizine tabi tutulmuştur. Araştırmaya katılan 557 Türkçe öğretmeni adayının "Akademik Erteleme Davranışı" ölçeğine vermiş oldukları cevaplar ölçeğin "Sorumsuzluk" , "Akademik Görevin Algılanan Niteliği", "Öğgretmenlere İlişkin Olumsuz Alg1”, “Akademik Mükemmeliyetçilik” boyutlarında ayrı ayrı hesaplanmıştır. Bu veriler Tablo 3’te sunulmuştur.

Tablo 3

Türkçe Öğretmeni Adaylarının Akademik Erteleme Davranışı Ölçeği Puanlarının Aritmetik Ortalama ve Standart Sapma Değerleri

\begin{tabular}{lcl}
\hline & $\overline{\mathbf{X}}$ & SS \\
\hline Sorumsuzluk & 2.62 & .83 \\
Akademik Görevin Algılanan Niteliği & 2.31 & .69 \\
Öğretmenlere İlişkin Olumsuz Alg1 & 3.15 & .95 \\
Akademik Mükemmeliyetçilik & 2.77 & .88 \\
\hline Akademik Erteleme Davranışı Ölçeği (Genel) & $\mathbf{2 . 6 2}$ & $\mathbf{. 6 1}$ \\
\hline
\end{tabular}

Tablo 3'te görüldüğü gibi akademik erteleme davranışı ölçeğinin alt boyutlarından "Sorumsuzluk" boyutuna ilişkin maddelerin ortalamasının orta düzeyde (2.62) olduğu, "Akademik Görevin Algilanan Niteliği” boyutuna ilişkin maddelerin ortalamasının düşük düzeyde $(\overline{\mathrm{X}}=2.31)$ olduğu, "Öğretmenlere İlişkin Olumsuz Algı" boyutuna ilişkin maddelerin ortalamasının orta düzeyde $(\overline{\mathrm{X}}=3.15)$ olduğu, "Akademik Mükemmeliyetçilik" boyutuna ilişkin maddelerin ortalamasının orta düzeyde ( $\overline{\mathrm{X}}=2.77)$ olduğu belirlenmiştir. Türkçe öğretmeni adaylarının Akademik Erteleme Davranışı Ölçeğinden aldıkları puanların genel ortalamasının ise orta düzeyde olduğu $(\bar{X}=2.62)$ belirlenmiştir. Buna göre, katılımcıların orta düzeyde akademik erteleme davranışı sergiledikleri söylenebilir.

\section{Akademik Öz Yeterliğe İlişkin Bulgular}

Türkçe öğretmeni adaylarının akademik öz yeterlik düzeylerini belirlemek için öğretmen adaylarının Akademik Öz yeterlik Ölçeğinden aldıkları puanlar betimsel istatistik analizine tabi tutulmuştur. Araştırmaya katılan 557 Türkçe öğretmeni adayının “Akademik Öz yeterlik" ölçeğine vermiş oldukları cevaplar ölçeğin “Bilişsel Uygulama” , “Sosyal Statü” , “Teknik Beceriler” boyutlarında ayrı ayrı hesaplanmıştır. $\mathrm{Bu}$ veriler Tablo 4'te sunulmuştur.

Tablo 4

Türkçe Öğretmeni Adaylarının Akademik Öz yeterlik Ölçeği Puanlarını Aritmetik Ortalama ve Standart Sapma Değerleri

\begin{tabular}{lcc}
\hline & $\overline{\mathbf{X}}$ & SS \\
\hline Bilişsel Uygulama & 3.21 & .58 \\
Sosyal Statü & 2.83 & .67 \\
Teknik Beceriler & 3.02 & .76 \\
\hline Akademik Öz Yeterlik Ölçeği (Genel) & $\mathbf{3 . 0 7}$ & $\mathbf{. 5 6}$ \\
\hline
\end{tabular}


Tablo 4'te görüldüğü gibi akademik öz yeterlik ölçeğinin alt boyutlarından "Bilişsel Uygulama" boyutuna ilişkin maddelerin ortalamasının orta düzeyde $(\overline{\mathrm{X}}=3.21)$ olduğu, "Sosyal Statü" boyutuna ilişkin maddelerin ortalamasının orta düzeyde $(\overline{\mathrm{X}}=2.83)$ olduğu, "Teknik Beceriler" boyutuna ilişkin maddelerin ortalamasının orta düzeyde ( $\overline{\mathrm{X}}=3.02)$ olduğu belirlenmiştir. Türkçe öğretmeni adaylarının Akademik Öz yeterlik Ölçeğinden aldıkları puanların genel ortalamasının ise orta düzeyde olduğu $(\bar{X}=3.07)$ belirlenmiştir. Buna göre katılımcıların akademik öz yeterlik açısından kendilerini orta düzeyde algıladıkları söylenebilir.

\section{Akademik Erteleme Davranışı ve Akademik Öz yeterlik Düzeyleri Arasındaki İlişkiyi Ortaya Koyan Bulgular}

Türkçe öğretmeni adaylarının Akademik Erteleme Davranışı Ölçeği'nden ve Akademik Öz yeterlik Ölçeğinden aldıkları puanlar arasındaki ilişki korelasyon analizi ile sınanmış ve sonuçlar Tablo 5'te verilmiştir.

Tablo 5

Akademik Erteleme Davranışı ile Akademik Öz yeterlik Ölçeklerinden Elde Edilen Puanlar Arasındaki İlişkiyi Ortaya Koyan Pearson Korelasyon Analizi Sonuçlar

\begin{tabular}{|c|c|c|c|c|c|c|c|c|c|}
\hline Ölçekler / Boyutlar & 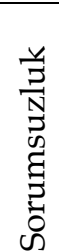 & 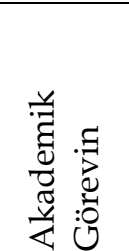 & 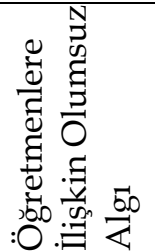 & 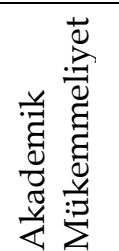 & 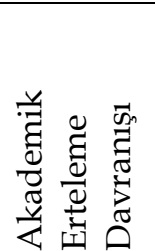 & 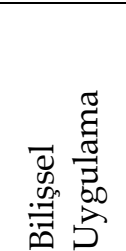 & 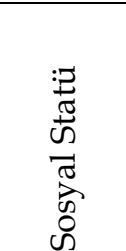 & 弟 & 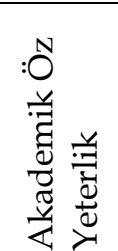 \\
\hline Sorumsuzluk & & $.483^{* *}$ & $.368^{* *}$ & $.298^{* *}$ & $.937^{* *}$ & $-.391^{* *}$ & $-.160^{* *}$ & $-.285^{* *}$ & $-.342^{* *}$ \\
\hline $\begin{array}{l}\text { Akademik Görevin } \\
\text { Algilanan Niteliği }\end{array}$ & & & $.156^{* *}$ & .068 & $.662^{* *}$ & $-.372^{* *}$ & $-.101^{*}$ & $-.255^{* *}$ & $-.304^{* *}$ \\
\hline $\begin{array}{l}\text { Öğretmenlere İlişkin } \\
\text { Olumsuz Alg1 }\end{array}$ & & & & $.236^{* *}$ & $.533^{* *}$ & $-.168^{* *}$ & $-.087^{*}$ & $-.087^{*}$ & $-.148^{* *}$ \\
\hline $\begin{array}{l}\text { Akademik } \\
\text { Mükemmeliyetçilik }\end{array}$ & & & & & $.420^{* *}$ & $-.111^{* *}$ & -0.054 & -0.033 & $-.092^{*}$ \\
\hline $\begin{array}{l}\text { Akademik Erteleme } \\
\text { Davranışı }\end{array}$ & & & & & & $-.424^{* *}$ & $-.163^{* *}$ & $-.290 * *$ & $-.364^{* *}$ \\
\hline Bilişsel Uygulama & & & & & & & $.631^{* *}$ & $.651^{* *}$ & $.943^{* *}$ \\
\hline Sosyal Statü & & & & & & & & $.527^{* *}$ & $.834^{\star *}$ \\
\hline Teknik Beceriler & & & & & & & & & $.752^{* *}$ \\
\hline $\begin{array}{l}\text { Akademik Öz } \\
\text { Yeterlik }\end{array}$ & & & & & & & & & \\
\hline
\end{tabular}

Korelasyon katsayısı 0-.30 arasındaysa değişkenler arasında ilişkinin olmadığını, .31-.49 aralığındaysa değişkenler arasında zayıf ilişkiyi, .50-.69 aralığındaysa değiş̧kenler arasında orta düzeyde bir iliş̧iye ve .70-1.00 aralığındaysa değişkenler arasında yüksek (güçlü) ilişkinin olduğunu ifade eder (Sönmez ve Alacapınar, 2011). Buradan hareketle Tablo 5'teki veriler incelendiğinde, Akademik Erteleme Ölçeği düzeylerinden Sorumsuzluk ile Akademik Görevin Algılanan Niteliği arasında (.483), Sorumsuzluk ile Öğretmenlere İlişkin Olumsuz Alg1 düzeyleri arasında (.368) ve Akademik Mükemmeliyetçilik ile Akademik Erteleme Davranışı arasında (.420) pozitif yönde düşük bir ilişki bulunmaktadır. Akademik Görevin Algılanan Niteliği ile Akademik Erteleme Davranışı arasında (.662) ve Akademik 
Mükemmeliyetçilik, Öğretmenlere İlişkin Olumsuz Alg1 arasında (.533) pozitif yönde orta derecede ilişki olduğu belirlenmiştir. Sorumsuzluk ile Akademik Erteleme Davranışı arasında (.937) pozitif yönde güçlü ilişkinin olduğu görülmektedir. Akademik Erteleme Davranışı ile Akademik Öz yeterlik ölçeklerinin düzeyleri arasındaki ilişkiler incelendiğinde, Sorumsuzluk ile Bilişsel Uygulama arasında (.391), Sorumsuzluk ile Akademik Öz yeterlik arasında (-.342), Akademik Görevin Algılanan Niteliği ile Bilişsel Uygulama düzeyleri arasında (-.372), Akademik Görevin Algılanan Niteliği ile Akademik Öz yeterlik arasında (-.304), Akademik Erteleme Davranışı ile Bilişsel Uygulama arasında (-.424) ve Akademik Erteleme Davranışı ile Akademik Öz yeterlik arasında (-.364) negatif yönde düşük seviyede ilişkilerin olduğu görülmektedir. Bununla birlikte, Akademik Öz yeterliğin alt boyutları ile pozitif yönde güçlü ilişkileri olduğu görülürken, alt boyutlarının kendi aralarında orta seviyede pozitif yönlü ilişkiye sahiptirler. Bunların dışında kalan boyutlar arasında ise anlamlı bir ilişkinin bulunmadığı söylenebilir.

Tablo 6

Akademik Öz yeterliğin Akademik Erteleme Davranışı Üzerindeki Etkisine İlişkin Çoklu Regresyon Analizi Verileri

\begin{tabular}{|c|c|c|c|c|c|c|c|c|}
\hline & & B & SEB & B & $\mathbf{t}$ & Sig. & Tolerance & VIF \\
\hline 1 & (Sabit) & 3.984 & .133 & & 30.052 & $.000^{* *}$ & & \\
\hline 2 & Bilişsel Uygulama & -.527 & .059 & -.502 & -8.966 & $.000^{* *}$ & .461 & 2.169 \\
\hline 3 & Sosyal Statü & .170 & .046 & .186 & 3.714 & $.000^{* *}$ & .578 & 1.729 \\
\hline 4 & Teknik Beceriler & -.049 & .041 & -.061 & -1.189 & .235 & .553 & 1.807 \\
\hline
\end{tabular}

Tablo 6'daki verilerden hareketle akademik öz yeterliğin, akademik erteleme davranışını yordayıp yordamadığına bakıldığında ise "Teknik Beceriler" hariç diğer akademik öz yeterlik boyutlarının akademik erteleme davranışını yordadığı görülmektedir. Bilişsel uygulama düzeyindeki 1 birimlik artış, akademik erteleme davranışı düzeyini .527 birim azaltmakta iken, sosyal statü düzeyindeki 1 birimlik artış, akademik erteleme davranışı düzeyini .170 birim artırmaktadır. Adı geçen değişkenlerin akademik ertelemenin \% 19.6'sını açıklamadığı belirlenmiş $\left(\mathrm{R}^{2}=.196\right)$, akademik ertelemenin \% 80.4'ünün modele dâhil edilmeyen diğer değişkenler tarafından açıklandığı belirlenmiştir. "Teknik Beceriler" düzeyinin ise akademik erteleme düzeylerini yordamadığı belirlenmiştir $(p=.235>.05)$.

\section{Sonuç ve Tartışma}

Akademik erteleme davranışı ve akademik öz yeterlik kavramlarının Türkçe öğretmeni adaylarındaki düzeylerinin ve iki kavramın arasındaki ilişkinin tespit edilmesinin amaçlandığı bu araştırmada şu sonuçlara ulaşılmıştır:

Türkçe öğretmeni adaylarının akademik erteleme davranışı düzeylerini tespit etmek amacıyla Türkçe öğretmeni adaylarına Akademik Erteleme Davranışı Ölçeği (Ocak ve Bulut, 2015) uygulanmış ve ölçeğe yapılan tanımlayıcı istatistikler neticesinde ölçeği oluşturan Sorumsuzluk, Akademik Görevin Algılanan Niteliği, Öğretmenlere İlişkin Olumsuz Algı, Akademik Mükemmeliyetçilik boyutlarının ortalamaların dengeli dağıldığ1 belirlenmiştir. Akademik Erteleme Davranışı Ölçeği genel aritmetik ortalamasının orta düzeyde olduğu tespit edilmiştir. Bu çalışmada görüldüğü gibi 
akademik eteleme davranışının bireylerde orta düzeyde olduğu sonucunu destekleyen ve yaygin bir sorun olduğunu ortaya koyan bir birçok çalışma mevcuttur (Bulut ve Ocak, 2017; Çetin, 2009; Engin ve Genç, 2020; Sarıkaya-Aydın ve Koçak,2016; Özer, 2005; Uzun Özer, 2009; Vural ve Gündüz, 2019). Akademik erteleme davranışının öğretmen adaylarında orta düzeyde görülmesi önemli bir sorundur. Gelecek nesilleri yetiştirecek olan öğretmen adaylarının eğitim fakültelerinden mezun olduğunda donanımlı bireyler olarak mesleklerini icra edebilmeleri için akademik görevlerini zamanında eksiksiz yerine getirebilme bilincinde olmalıdırlar. Çünkü, eğitimde yapılan ertelemeler telafisi olmayan sonuçlar doğuracaktır.

Akademik ertelemenin orta düzeyde çıkması yani öğretmen adaylarının akademik görevlerini ertelemelerinin nedeni düşünüldüğünde bu araştırmada kullanılan ölçeğin boyutlarında ulaşılan ortalamalar bu soruyu cevaplayacaktır. Akademik erteleme davranışının genel ortalaması dışında ölçeğin boyutlarının ortalamalarıyla ilgili bulgularda Türkçe öğretmeni adaylarının, "Akademik Görevin Algılanan Niteliği" boyutunda düşük düzeyde bir puana sahip oldukları, diğer boyutlarda orta düzeyde bir puana sahip oldukları sonucuna ulaşılmıştır. Bu sonuç, Türkçe öğretmeni adaylarının akademik erteleme davranışına yönelmelerinde, görevlerin uzun-kısa, kolay-zor, sıkıcı-ilgi çekici gibi nitelendirmelerin az etkili olduğu fakat öğretmen adaylarının erteleme davranışına yönelmelerinde etkili olduğu görülmektedir. $\mathrm{Bu}$ nedenle, verilen görevlerin daha dikkatli seçilmesi erteleme davranışının azalmasında etkili olacaktır. Akademik Erteleme Davranışı Ölçeğinin Sorumsuzluk, Öğretmenlere İlişkin Olumsuz Algı, Akademik Mükemmeliyetçilik boyutlarının ortalamaları incelendiğinde; öğretmen adaylarının akademik görevleri yapmak için istekli olmamaları, verilen bir görevi mükemmel bir şekilde yapmak için gereğinden fazla zaman harcayıp zaman yönetimi yapamamaları ve sorun yaşamaları (Kağan, 2009; Sarıkaya-Aydın ve Koçak, 2016), görevi veren öğretmene hakkındaki olumsuz algıları akademik erteleme davranışı göstermelerinde etkili olmuştur.

Türkçe öğretmeni adaylarının akademik öz yeterlik düzeylerini tespit etmek amacıyla Türkçe öğretmeni adaylarına Akademik Öz yeterlik Ölçeği (Ekici, 2012) uygulanmış, yapılan tanımlayıcı istatistikler neticesinde Bilişsel Uygulamalar, Sosyal Statü, Teknik Beceriler boyutlarından oluştuğu ve ortalamaların dengeli dağıldığı saptanmıştır. Bütün boyutların puanlarının orta düzeyde olduğu belirlenmiştir. Akademik Öz yeterlik Ölçeğinin alt boyutları incelendiğinde, sosyal statü boyutunda Türkçe öğretmeni adaylarının sınıftaki tartışmalara katılma, derse düzenli katılma, anlamadığ1 bir kavramı öğretim elemanından tekrar anlatmasını isteme, öğretim elemanının düşüncesini yargılama ve ders dışı kulüp veya etkinliklere katılma gibi konularda yüksek öz yeterliğe sahip olmadıkları görülmektedir. Bilişsel uygulama boyutunda düzenli not tutma, nitelikli bir ödev yazma, bir konu veya kavramı arkadaşlarına anlatma, okuduğu metindeki fikirleri anlama gibi konularda yüksek öz yeterliğe sahip olmadıkları görülmektedir. Teknik beceriler boyutunda da ders içeriğini diğer derslerin materyalleri ile ilişkilendirme, kütüphaneyi güzel kullanma, ders içeriğini atölyede uygulama gibi konularda yüksek öz yeterliğe sahip olmadıkları görülmektedir. Akademik Öz yeterlik Ölçeği genel aritmetik ortalamasının orta düzeyde olduğu tespit edilmiştir. Bu sonuçla aynı doğrultuda birçok çalışmaya literatürde rastlanmaktadır (Doruk ve Kaplan, 2012; Saracoğlu, Karasakaloğlu ve Evin Gencel 2010; Turğut, 2013). 
"Akademik Erteleme Davranışı" ve "Akademik Öz Yeterlik" ölçeklerinin boyutları arasındaki ilişki incelendiğinde Sorumsuzluk ile Bilişsel Uygulama arasında, Sorumsuzluk ile Akademik Öz yeterlik arasında, Akademik Görevin Algılanan Niteliği ile Bilişsel Uygulama düzeyleri arasında, Akademik Görevin Algılanan Niteliği ile Akademik Öz yeterlik arasında, Akademik Erteleme Davranışı ile Bilişsel Uygulama arasında negatif yönde düşük seviyede ilişkilerin olduğu tespit edilmiştir. Ayrıca, Akademik Erteleme Davranışı Ölçeğinin alt boyutları arasındaki ilişkilere bakıldığında, Sorumsuzluk ile Akademik Görevin Algılanan Niteliği arasında, Sorumsuzluk ile Öğretmenlere İlişkin Olumsuz Algı düzeyleri arasında, Akademik Mükemmeliyetçilikle Akademik Erteleme Davranışı arasında pozitif yönde zayıf bir ilişki bulunduğu saptanmıştır. Akademik Görevin Algılanan Niteliği ile Akademik Erteleme Davranışı arasında, Öğretmenlere İlişkin Olumsuz Algıyla Akademik Erteleme Davranışı arasında pozitif yönde orta derecede ilişki olduğu belirlenmiştir. Sorumsuzlukla Akademik Erteleme Davranışı arasında pozitif yönde güçlü ilişkinin olduğu bulgulanmıştır. Araştırmanın korelasyon analizinden elde edilen bu sonuçta akademik erteleme davranışı ile sorumsuzluk boyutu arasında pozitif yönde güçlü bir ilişki çıkması bir tesadüf değildir. Çıkan sonuca göre sorumsuzluk arttıkça akademik erteleme davranışının artacağı, sorumsuzluk azaldıkça akademik erteleme davranışının azalacağı anlaşılmaktadır. Bu durumda, Türkçe öğretmeni adaylarını sorumsuzluk yapıp akademik erteleme davranışı göstermeye iten plansız olma, işleri önem sırasına koyamama, çalışma motivasyonu olmama, yetersiz güdülenme, çok çaba gerektiren görevlerde sıkılma, başarısız olma kaygısı, zaman israfı, bir işe göreve kadar zaman ayıracağını bilememe gibi birçok sebep olduğu düşünülebilir. Özer ve Altun (2011), yaptıkları bir çalışmada ulaşılan sonucu destekler nitelikte sorumluluğu düşük öğrencilerin başarısızlık korkusu ve tembellik nedeniyle akademik erteleme yaptıklarını belirtirlerken, Engin ve Genç (2020,) akademik görev için gerekli davranışların sonuçlarının algılanamaması ve sonuçların üstlenilmekten kaçınılmasının sorumsuzluğa neden olduğunu ve beraberinde akademik ertelemeyi getirdiğini belirtmektedirler. Ayrıca, öğrencilerin sınıf içinde arkadaşları ve öğretim elemanları tarafından yaptığı bir görev nedeniyle olumsuz değerlendirilme korkusu yaşamaları görevi yapmaktan kaçınmalarına, sorumsuzluk sergilemelerine ve görevi ertelemelerine sebep olmuştur (Berber Çelik ve Odacı, 2015).

Araştırmanın bulgularında akademik erteleme davranışıyla akademik öz yeterlik arasındaki ilişkiye bakıldığında negatif yönde düşük bir ilişki olduğu sonucuna ulaşılmıştır. Sonuç olarak, akademik erteleme davranışı arttıkça akademik öz yeterliğin azaldığı, akademik erteleme davranışı azaldıkça akademik öz yeterliğin arttığ1 tespit edilmiştir. Literatür incelendiğinde, bu ilişkiyi destekleyen sonuçların olduğu çalışmalara rastlanmaktadır (Akbay ve Gizir, 2010; Aydoğan, 2008; Berber Çelik, 2014; Kandemir, 2010; Pfister, 2002; Sirois, 2004; Wang, Qian, Wang ve Chen, 2011; Wolters, 2003). Bu sonuçta görüldüğü üzere akademik görev verilen öğretmen adayının bölümüyle ilgili öz yeterliği yüksekse verilen görevi erteleme davranışı göstermeden yerine getirecektir. Öz yeterliği yüksek birey, bir görevi nasıl yapacağını ve bu görev için gerekli dokümanları nerede bulacağını bilip endişeye kapılmadan, başarısızlık korkusu yaşamadan, görevini mükemmel bir şekilde yaptığına inanarak zaman kaybına sebebiyet vermeden yerine getirecektir. Yani, bireyin akademik görev veya herhangi bir alanla ilgili konu hakkında öz yeterliğinin yüksek olması bireyin 
motive olması ve görevi devam ettirmesinde önemli bir husustur (Berber Çelik ve Odac1, 2015).

Türkçe öğretmeni adaylarının akademik öz yeterliklerinin akademik erteleme davranışını yordayıp yordamadığını çözümlemek için yapılan çoklu regresyon analizi sonucuna bakıldığında, "Teknik Beceriler" hariç diğer akademik öz yeterlik boyutlarının akademik erteleme davranışını yordadığı görülmüştür. Bu sonuçta açıkçası şunu görmekteyiz: Türkçe öğretmenliği programı bünyesindeki öğretmen adaylarına alan dersi olarak anlama ve anlatmaya dayalı becerilerle (dinleme, okuma, konuşma, yazma) ilgili yeterlikler kazandırılmaya çalışıldığı için ve kas gücüyle yapılacak etkinliklere fazla yer olmaması nedeniyle teknik beceriler boyutunun erteleme davranışını yordamaması olağan bir sonuç olarak görülebilir.

\section{Öneriler}

Akademik erteleme davranışı ile akademik öz yeterlik arasındaki korelasyon ilişkisine bakıldığında negatif yönde düşük bir ilişki olsa da sonuç olarak akademik erteleme davranışı arttıkça akademik öz yeterlik azalmakta, akademik erteleme davranışı azaldıkça akademik öz yeterlik artmaktadır. Bu noktada, Türkçe öğretmeni adaylarına üniversitelerin ilgili birimlerince sorumluluk bilinci kazanmaları, mükemmeliyetçilik konusunda dengeyi sağlayıp zamanı yönetebilmeleri, verilen akademik görevlerin gerekliliği bilincinin oluşması, öğretim elemanlarına ilişkin olumlu bir tutum geliştirmeleri, sınıf içi ve sınıf dışı yeterlikler konusunda bilinçlendirilmeleri, üniversitedeki atölye, kütüphanelerden yararlanmaları gibi konularda gerekli rehberlik çalışmaları yapılabilir.

Türkçe öğretmeni adaylarını teknik beceriler yönünden yetkin hale getirebilmek için üniversitelerde öğretim teknolojileri ve materyal tasarımı dersine gereken önemin verilip öğretmen adaylarının Türkçe eğitiminde yer alan becerilerle bütünleştirebilecekleri, çalışıp materyal üretebilecekleri, zihin ve kas gücünü birleştirebilecekleri ortamlar sağlanabilir.

Akademik Erteleme Davranışı Ölçeği ve Akademik Öz yeterlik Ölçeği boyutlarının farklı değişkenlerle veya tek başına ayrıntılı bir şekilde incelenerek nedenleri üzerine açıklamalar getirilebilir.

Araştırma Türkiye' deki devlet üniversitelerinde bulunan 4. sınıf Türkçe öğretmeni adaylarından elde edilen verilerle sınırlı olduğu için farklı örneklem gruplarıyla ve farklı kültürlerle yapılacak çalışmalar farklı sonuçlar ortaya koyacaktır. $\mathrm{Bu}$ araştırma nicel verilerle gerçekleştirilmiştir. Bu konu üzerinde, nitel veya karma araştırma yöntemleri kullanılarak yeni araştırmalar yapılabilir.

\section{Kaynakça}

Açıkgöz Ün, K. (2003). Etkili öğrenme ve öğretme. İzmir: Eğitim Dünyası Yayınları.

Akbay, S. E. ve Gizir, C. A. (2010). Cinsiyete göre üniversite öğrencilerinde akademik erteleme davranışı: Akademik güdülenme, akademik öz yeterlik ve akademik yükleme stillerinin rolü. Mersin Üniversitesi Ĕ̆gitim Fakültesi Dergisi, 6(1), 60-78.

Akkaya, E. (2007). Academic procrastination among faculty of education students: The role of gender, age, academic achievement, perfectionism and depression. (Yayımlanmamış yüksek lisans tezi), Ankara: Ortadoğu Teknik Üniversitesi Eğitim Bilimleri Enstitüsü. 
Aydoğan, D. (2008). Akademik erteleme davranışının benlik saygısı, durumluluk kaygı ve öz-yeterlik ile açıklanabilirliği. (Yayımlanmamış yüksek lisans tezi), Ankara: Gazi Üniversitesi Eğitim Bilimleri Enstitüsü.

Balkıs, M. (2006). Öğretmen adaylarının davranışlarındaki erteleme eğiliminin, düşünme ve karar verme tarzlan ile ilişkisi. (Yayınlanmamış doktora tezi), İzmir: Dokuz Eylül Üniversitesi Eğitim Bilimleri Enstitüsü Eğitim Bilimleri Anabilim Dalı.

Balk1s, M. ve Duru, E. (2009). Prevalence of academic procrastination behavior among pre-service teachers, and its relationship with demographics and individual preferences. Eğitimde Kuram ve Uygulama, 5(1), 18-32.

Beck, B. L., Koons, S. R., and Milgrim, D. L. (2000). Correlates and consequences of behavioral procrastination: The effects of academic precrastination, self conciousness, self-esteem and self-handicapping. Journal of Social Behavior and Personality, 15(5), 3-13.

Berber Çelik, Ç. ve Odacı H. (2015). Akademik erteleme davranışının bazı kişisel ve psikolojik değişkenlere göre açıklanması. Hacettepe Üniversitesi Ĕ̆itim Fakültesi Dergisi, 30(3): 31-47.

Berber Çelik, Ç. (2014). Akademik ertelemenin bazı psiko-sosyal değişkenlere göre açıklanması ve gerçeklik terapisine dayalı akademik erteleme ile başa çıkma eğitim programının etkililiğinin sınanması. (Yayınlanmamıs doktora tezi), Trabzon: Karadeniz Teknik Üniversitesi Eğitim Bilimleri Enstitüsü.

Beswick, G., Rothblum, E. D., and Mann, L. (1988). Psychological antecedents of student procrastination. Australian Psychologist, (23), 207-217. https://doi.org/10.1080/00050068808255605

Bulut, R. ve Ocak. G. (2017). Öğretmen adaylarının akademik erteleme davranışlarını etkileyen etmenler. E-Uluslararası Eğitim Araştırmaları Dergisi, 8(2), 75- 90.

Büyüköztürk, Ş. (2006). Sosyal Bilimler için veri analizi el kitabı-İstatistik, araştırma deseni SPSS uygulamaları ve yorum-. Ankara: Pegem Akademi.

Çakıcı, D. Ç. (2003). Lise ve üniversite öğrencilerinde genel erteleme ve akademik erteleme davranışının incelenmesi. (Yüksek lisans tezi), Ankara: Ankara Üniversitesi Eğitim Bilimleri Enstitüsü.

Çelikkaleli, Ö. ve Akbay, S. E. (2013). Üniversite öğrencilerinin akademik erteleme davranışı, genel yetkinlik inancı ve sorumluluklarının incelenmesi. Ahi Evran Üniversitesi Kırşehir Eğitim Fakültesi Dergisi (KEFAD), 14(2), 237-254.

Çetin, Ş. (2009). Ĕ̆itim fakültesi öğrencilerinin akademik erteleme davranışlarına ilişkin görüşlerinin incelenmesi. Gazi Üniversitesi Endüstriyel Sanatlar Eğitim Fakültesi Dergisi, 25, 1-7.

Doruk, M. ve Kaplan, A. (2012). Sınıf öğretmeni adaylarının matematik öğretimine yönelik öz-yeterlik inançlarının incelenmesi. The Journal of Academic Social Science Studies, 5(7), 291-302

Ekici, G. (2012). Akademik öz-yeterlik ölçeği: Türkçeye uyarlama, geçerlik ve güvenirlik çalışması. Hacette Üniversitesi Ĕ̆itim Fakültesi Dergisi, 43, 174-185.

Emmett, R. (2004). A ̈̆ustos böceği ile karınca. (Çeviren: Sara Çaşkurlu). İstanbul: Kariyer Yayınları

Engin, G ve Genç S. Z. (2020). Öğretmen adaylarının akıllı telefon ekran kullanım süreleri ile akademik erteleme davranışları arasındaki ilişkinin incelenmesi. 
Celal Bayar Üniversitesi Sosyal Bilimler Dergisi, 18(1); 314-325. https:// doi.org/10.18026/cbayarsos.678739

Grecco, P. R. (1984). A cognitive-behavioral assessment of problematic academic procrastination: Development of a procrastination self- statement inventory. (Unpublished dissertation), Fresno: California School of Professional Psychology.

Gülebağlan, C. (2003). Öğretmenlerin işleri son ana erteleme eğilimlerinin, mesleki yeterlilik algıları, mesleki deneyimleri ve branşları bakımından karşılaştırılmasına yönelik bir araştırma. (Yayınlanmamış yüksek lisans tezi). Ankara: Ankara Üniversitesi Eğitim Bilimleri Enstitüsü.

Güner, D. (2008). İlköğretim okullarında görev yapan sınıf ve branş öğretmenlerinin erteleme eğilimleri ve kaygı düzeyleri. (Yüksek lisans tezi), İstanbul: Yeditepe Üniversitesi Sosyal Bilimler Enstitüsü.

Gürültü, E. (2016). Lise öğrencilerinin sosyal medya bağımlılıklarn ve akademik erteleme davranışları arasındaki ilişkinin incelenmesi. (Yüksek lisans tezi), İstanbul: Marmara Üniversitesi Eğitim Bilimleri Enstitüsü.

Haycock, L. A., Mccarthy, P., and Skay, C. L. (1998). Procrastination in college students: The role of self-efficacy and anxiety. Journal of Counseling and Development, (76), 317-324. https:// doi.org/10.1002/j.15566676.1998.tb02548.x

Kağan, M. (2009). Üniversite öğrencilerinde akademik erteleme davranışını açıklayan değişkenlerin belirlenmesi. Ankara Üniversitesi Ĕ̆itim Bilimleri Fakültesi Dergisi, 42(2), 133-128. https:/ / doi.org/10.1501/Egifak_0000001187

Kandemir, M. (2010). Akademik erteleme davranışını açıklayıcı bir model. (Yayınlanmamış doktora tezi), Ankara: Gazi Üniversitesi, Eğitim Bilimleri Enstitüsü.

Karasar, N. (2012). Bilimsel araştırma yöntemi. Ankara: Nobel Yayın Dağıtım.

Kavrayıcı, C. ve Bayrak, C. (2016). Öğretmen adaylarının öz-yeterlik algıları. Adıyaman Üniversitesi Sosyal Bilimler Enstitüsü Dergisi, 8(23), 623-658. https:// doi.org/10.14520/adyusbd.70805

Mccown, W., Petzel, T., and Rupert, P. (1987). An experimental study of some hypothesized behaviors and personality variables of college student procrastinators. Personality and Individual Differences, 8(6), 781-786. https:// doi.org/10.1016/0191-8869(87)90130-9

Milgram, N., Mey-Tal, G., and Levison, Y. (1998). Procrastination, generalized or specific, in college students and their parents. Personality and Individual Differences, 25(2), 297-316. https:// doi.org/10.1016/S0191-8869(98)00044-0

Ocak, G. ve Bulut, R. (2015). Akademik erteleme davranışı ölçeği: Geçerlilik ve güvenirlilik çalışması. International Journal of Social Sciences and Education Research, 1(2), 709-726. https:/ / doi.org/10.24289/ijsser.106455

Odac1, H. ve Berber Çelik, Ç. (2012). Üniversite öğrencilerinin problemli internet kullanımlarının akademik öz-yeterlik, akademik erteleme ve yeme tutumları ile ilişkisi. E-Journal of New World Sciences Academy NWSA-Education Sciences, 1c0504, 7(1), 389-403.

Owen, S. and Froman, R. D. (1988). Development of a college academic self- efficacy scale. Paper Presented at the Annual Meeting of the National Council on Measurement in Edecation, New Orleans, LA. 
Özer, B. U. (2005). Academic procrastination: Prevalance, self-reported reasons, gender difference and it's relation with academic achievement. (Yayınlanmamış yüksek lisans tezi). Ortadoğu Teknik Üniversitesi, Sosyal Bilimler Enstitüsü, Ankara.

Pfister, T. (2002). The effect of self-monitoring on academic procrastination, self eficacy and achievement. The Florida State University College of Education, Florida.

Polat, S. (2009). Türkiye'de eğitim politikalarının firsat eşitsizliği üzerindeki etkileri. (Yayınlanmış planlama uzmanlığı tezi), Ankara: Devlet Planlama Teşkilatı Yayınlar1.

Saracoğlu A. S., Karasakaloğlu N. and Evin Gencel İ. (2010). Türkçe Öğgretmenlerinin Özyeterlik Düzeylerinin Çeşitli Değişkenlere Göre İncelenmesi. Elektronik Sosyal Bilimler Dergisi, 9(33), 265-283.

Sarıkaya-Aydın, K. ve Koçak,S. (2016). Üniversite öğrencilerinin zaman yönetimi becerileri ile akademik erteleme düzeylerinin incelenmesi. Uşak Üniversitesi Eğitim Araştırmaları Dergisi, 2(3), 17-38. https:/ / doi.org/10.29065/usakead.256378

Sarıoğlu, A. F. (2011) Öğretmen adaylarının akademik erteleme eğilimi ile mükemmeliyetçilik düzeyleri arasındaki ilişki. (Yüksek lisans tezi), İstanbul: İstanbul Üniversitesi Sosyal Bilimler Enstitüsü.

Schunk, D. H. (1985) Self-efficacy and classroom learning. Psychology in The Schools, 22(2), 208-223. https:/ / doi.org/10.1002/1520-6807(198504)22:2<208::AIDPITS2310220215>3.0.CO;2-7

Senemoğlu, N. (2007). Gelişim, öğrenme ve öğretim. Ankara: Özkan Matbaası.

Shanahan, M. J. and Neufeld, W. J. (2010). "I'll go to therapy, eventually": Procrastination, stress and mental health. Personality and Individual Differences 49(2010) 175-180. https:/ / doi.org/10.1016/j.paid.2010.03.028

Sirois, F. (2004). Procrastination and intentions to perform health behaviors: The role of self-efficacy and the consideration of future consequences. Personality and Individual Differences, 37(1), 115-128. https:// doi.org/10.1016/j.paid.2003.08.005

Solomon, L. J. and Rothblum, E. D. (1984). Academic procrastination: Frequency and cognitive-behavioral correlates. Journal of Counseling Psychology, 31(4), 503509. https:/ / doi.org/10.1037/0022-0167.31.4.503

Tabancalı, E. ve Çelik, K. (2013). Öğretmen adaylarının akademik öz-yeterlikleri ile öğretmen öz-yeterlilikleri arasındaki ilişki. International Journal of Human Sciences, 10(1), 1167-1184.

Tice, D. M. and Baumeister, R. F. (1997). Longitudinal study of procrastination, performance, stress, and health. Psychological Science, 8(6), 454-458. https:/ / doi.org/10.1111/j.1467-9280.1997.tb00460.x

Turgut, M. (2013). Academic self-efficacy beliefs of undergraduate mathematics education students. Acta Didactica Napocensia, 6(1), 33-40

Uzun Özer B. (2009). Academic Procrastination in Group of High School Students: Frequency, Possible Reasons and Role of Hope. Turkish Psychological Counseling and Guidance Journal, 4(32), 12-19

Van Eerde, W. (2003). A meta-analytically derived nomological network of procrastination. Personality and Individual Differences, 35(6), 1401-1418. https:// doi.org/10.1016/S0191-8869(02)00358-6 
Vural, L., ve Gündüz, G. F. (2019). Öğretmen adaylarının akademik erteleme davranışları ile bilişsel farkındalık düzeyleri arasındaki ilişki. İlköğgretim Online, 18(1), 307-330. https://doi.org/10.17051/ilkonline.2019.527226

Wang, M., Qian, M., Wang, W. and Chen, R. (2011). Effects of group counseling based on self-efficacy for self-regulated learning in students with academic procrastination. Chinese Mental Health Journal, 25(12), 921-926.

Wolters, C. A. (2003). Understanding procrastination from a self-regulated learning perspective. Journal of Educational Psychology, 95(1), 179-187.

https:/ / doi.org/10.1037/0022-0663.95.1.179

\section{Summary}

Teachers who have the qualifications required by their profession should not choose the way to postpone their duties while using these qualifications and transferring them into daily life. For this, it is thought that it will be beneficial to examine the concepts of "academic self-efficacy" and "academic procrastination behaviour", to determine the competencies of Turkish teacher undergraduate program students and to offer suggestions.

Different definitions were made on both variables that were emphasized in the research. In general, postponement is defined as the task to be left to another time, while Grecco (1984) refers to postponement as delaying by deliberately and intentionally to take action or complete a job. Shunk (1985) expresses academic selfefficacy as students' confidence in doing educational tasks.

There may be many reasons for academic procrastination and academic selfefficacy to be realized in a negative dimension in teacher candidates. In the literature, about academic procrastination behaviour; it is stated that reasons such as dislike of work, lack of motivation, perfectionism, fear of failure, fear of change, the intensity of workload of individuals, development of technology and industry, gender, low selfesteem, anxiety are effective. People with high self-efficacy can act without hesitation to fulfill the tasks they encounter and plan to perform in the best way without wasting time and effort. People with low self-efficacy can postpone the tasks they need to do constantly; they may experience high anxiety and stress due to lack of time, knowledge and skills.

In this study, the main aim of which was to determine the opinions of Turkish teacher candidates regarding academic procrastination behaviour and academic selfefficacy levels and to reveal the relationship between them, the following questions were also answered:

1. What is the level of academic procrastination behaviour of Turkish teacher candidates ("irresponsibility", "perceived quality of academic duty", "negative perception of teachers", "academic perfectionism" sub-dimensions)?

2. What is the level of academic self-efficacy (in terms of "social status", "cognitive practices" and "technical skills") of Turkish teacher candidates?

3. Is there a relationship between academic procrastination behaviour of Turkish teacher candidates and academic self-efficacy? 


\section{Method}

A relational research model was used to determine the relationship between the academic procrastination behaviour of the Turkish teacher candidates and their academic self-efficacy. The sample of study was 2017-2018 academic year Turkish Language Teaching Program students studying in 13 different state universities, faculties of education in Turkey. Participants were taken from 12 statistical regions units from a total of 13 cities (Istanbul, Edirne, Afyonkarahisar, Bolu, Konya, Adana, Kirsehir, Nevsehir, Istanbul, Adana, Agri, Mus, Gaziantep) that was determined by Turkey Statistical Institute (TSI) according to the statistical regional units classification (Parker, 2009). "Academic Procrastination Scale" (Ocak and Bulut, 2015), "Academic Self-efficacy Scale" (Ekici, 2012), and "Personal Information Form", which is used to determine the demographic information of the participants, were used as data collection tools. 557 Turkish language teacher candidates answered these measurement tools used in the research. The data obtained as a result of the responses of the participants were transferred to the computer environment and statistical operations were applied such as frequency, mean, standard deviation calculation, Pearson Correlation Coefficient, multiple regression. The data analysis was performed using the SPSS 25.0 package program.

\section{Results}

As a result of the statistical operations that were employed to determine the levels of academic procrastination behaviour of the Turkish teacher candidates, the overall average dimensions of Irresponsibility (2.62), Negative Perception of Teachers (3.15), Academic Perfectionism (2.77) and Academic Procrastination Scale (2.62) were medium; however, it was found that the average score of the Perceived Quality of the Academic Position (2.31) was low.

As a result of the statistics performed to determine the academic self-efficacy levels of the Turkish teacher candidates, it has been concluded that the overall average of the Academic Self-Efficacy Scale (3.07) and the sub-dimensions of Cognitive Practice (3.21), Social Status (2.83), Technical Skills (3.02) are medium.

As a result of Pearson Correlation analysis, it was observed that there was a low negative relationship between academic procrastination behaviour and academic self-efficacy (-.364). As a result of the regression analysis, when it was examined, whether academic self-efficacy predicted academic procrastination behaviour, it was determined that all other academic self-efficacy dimensions predicted academic procrastination behaviour except "Technical Skills".

\section{Conclusion, Discussion and Pedagogical Implications}

Considering the general averages of Academic Procrastination and Academic SelfEfficacy as a result of the analyses, the teacher candidates have a moderate tendency in both variables; it was observed that there was a low level of relationship between both variables and they were predictors of each other. For teacher candidates, to have high self-efficacy in their fields and to minimize their procrastination behaviour, necessary guidance studies can be carried out by the relevant units of universities. More detailed qualitative and mixed research methods can be followed to reveal the reasons for this. 


\section{Araştırmanın Etik Taahhüt Metni}

Yapılan bu çalışmada bilimsel, etik ve alıntı kurallarına uyulduğu; toplanan veriler üzerinde herhangi bir tahrifatın yapılmadığı, karşılaşılacak tüm etik ihlallerde "Cumhuriyet Uluslararası Eğitim Dergisi ve Editörünün” hiçbir sorumluluğunun olmadığ1, tüm sorumluluğun Sorumlu Yazara ait olduğu ve bu çalışmanın herhangi başka bir akademik yayın ortamına değerlendirme için gönderilmemiş olduğu sorumlu yazar tarafından taahhüt edilmiştir.

\section{Authors' Biodata / Yazar Bilgileri}

Murat ŞENGÜL, Nevşehir Hacı Bektaş Veli Üniversitesi Eğitim Fakültesi Türkçe Eğitimi Anabilim Dalında öğretim üyesi olarak görev yapmaktadır. Yazar Türkçenin ana dili olarak öğretimi ve yabancı dil olarak Türkçe öğretimi alanlarında çalışmalar yürütmektedir.

Murat Sengul is a faculty member at Nevsehir Haci Bektas Veli University, Faculty of Education, Department of Turkish Language Education. He is working on teaching Turkish as a mother tongue and teaching Turkish as a foreign language.

Rafet Özer SEYFİ, Muş'un Bulanık ilçesinde bulunan Yokuşbaşı Ortaokulunda Türkçe öğretmeni olarak görev yapmaktadır.

Rafet Ozer Seyfi works as a Turkish teacher at Yokusbasi Secondary School in Bulanik district of Mus. 